\title{
Envisioning the Future of Reference Instruction
}

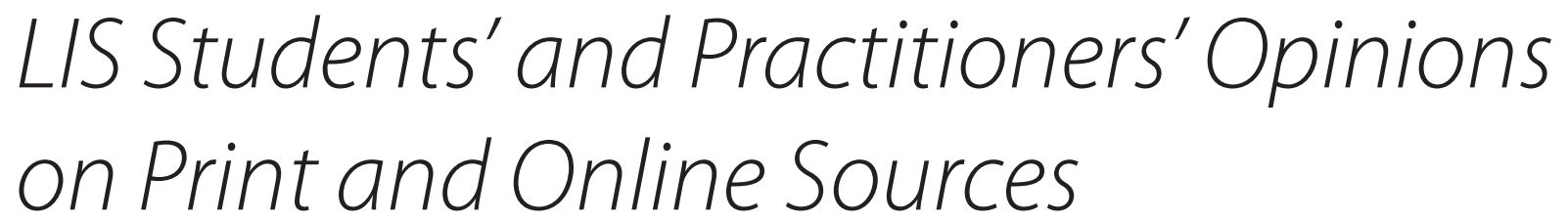

This paper examines students' and practitioners' attitudes toward, and uses of, various reference sources. It was precipitated by questioning the best outcomes of the basic reference class in Library Science programs, specifically asking what types of sources LIS students should be versed in as they enter the workforce-print or online? This research found some differences between academic and public librarians, and little agreement about the purposes of the basic reference course. Teaching about types of reference sources today is difficult; as Margaret Landesman says, we are moving away from "reference collections" because of "the convergence among formats, [so that] we can't recognize a reference book when we see one." Our students, though, might benefit from using print reference sources, less as a historical artifact, but for the concrete demonstration of organization of information that they offer.

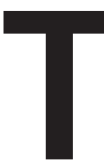
hough we discuss the phenomenon of "information overload" because of the Internet, the shift to the Internet for fact-finding and research is really another variation on a continued theme in reference service: too many sources. The bloated reference collection of the past resulted in a "needle in the haystack" phenomenon. Librarians couldn't know the entire collection, ${ }^{2}$ and users couldn't find what they wanted because of an overwhelming abundance of choices. Today's spare print reference collection is a response to an abundance of online resources and a shift in where our users are: less inside our walls, more outside. More and more, libraries are depending on online sources (databases and the free web) to fill out their reference collection. This variety of online resources is just as confusing to the patron (and the novice librarian) as those larger print collections were earlier.

The shift from print to online reference sources is not complete; it depends on whom the library serves. Academic libraries have different reference models from public libraries, influencing what types of resources they most often use. Academic libraries' patrons often access the library's collection from a distance. Public libraries' patrons tend to physically visit the library and ask questions in person. Generally, the literature says that reference models have made use of the shift to online access, with online reference transactions becoming more common, placing more importance still on the use of online reference sources. The literature related to reference work strongly suggests that librarians frequently work with virtual patrons using tools like texting and Facebook

\section{Jenny S. Bossaller and Denice Adkins}

Jenny S. Bossaller is Assistant Professor and Denice Adkins is Associate Professor, School of Information Science and Learning Technologies, University of Missouri, Columbia, Missouri. Submitted for review January 3, 2011; revised and accepted for publication July 7, 2011.

Reference \& User Services Quarterly, vol. 51, no. 2, pp. 63-72 (c) 2011 American Library Association. All rights reserved.

Permission granted to reproduce for nonprofit, educational use. 


\section{FEATURE}

to connect with patrons "where the patrons are." not universal, though, and is fundamentally problematic for some libraries.

This research began as a pedagogical problem-how to teach, or whether to teach, print resources in this new reference landscape, while utilizing a new pedagogical model in which classes are taught largely online, without regular faceto-face contact. Any reference class is constrained by having a limited amount of time and a considerable body of subject matter to be covered. Designing effective source instruction goes beyond choosing which sources to teach to choosing what is most important for students to learn. Deciding which sources to teach might be a decision based on instructor convenience. Deciding what is most important to learn demands a focus on students' needs and the needs of the profession.

To determine the sources and type of instruction that held value for students in class, and would hold value for them as professionals later on, we surveyed students in reference classes to find out what their opinions were on assignments. We also surveyed practitioners to determine what they felt new hires needed to know and what their own reference scenarios consisted of. Lastly, we interviewed professional librarians to learn more about their opinions of print and electronic source instruction. What skills and traits should new librarians possess? What can they learn in school, and what must they learn on the job?

\section{LITERATURE REVIEW}

Teaching reference and information retrieval has long occasioned reflection, from what sources should be taught to what blend of source instruction and interpersonal skills should be taught. In 1989, Samuel Rothstein asked,

What should reference instructors teach their students? Should the instruction concentrate on memorization of specific sources, usage of various types of sources, or should it be focused on communication and operational issues inherent in reference encounters? ${ }^{4}$

Even at that time, it was acknowledged to be a largely rhetorical question. John V. Richardson examines the teaching of reference work through Thomas Kuhn's view that textbooks "posit a paradigm — the 'normal science' or given way of doing things in certain fields."' Richardson takes a longitudinal approach in examining the teaching and the textbooks in coverage of materials and recommended methods for reference. He describes the evolution of the Guide to Reference Materials (which was written and edited by LIS professors of Reference) from the early 1900s through the (then) present. The Guide reflects what he calls a structuralist approach to reference, emphasizing the materials used for reference work. He delineates the differences between the structuralist's approach and the proceduralist's as a difference of "what to use during a reference encounter" versus "how to interact with a patron/user/customer." Textbooks certainly offer one way of looking at the problem, as the 'normal way' of doing reference. However, when we hear that librarians are veering far from the recommended sources (yet still getting the job done), how should education proceed? What is the normal way of doing things?

Denice Adkins and Sanda Erdelez provide a benchmark look at LIS educators' teaching methods and differences in their teaching online and print resources. ${ }^{6}$ They surveyed instructors of general and subject-specific reference classes including business reference and health information reference. Approximately 12 percent of their respondents indicated that they taught their reference courses completely online and 70 percent taught in a face-to-face format. However, no distinction was made to distinguish hybrid from face-to-face courses. They found that LIS educators have a hard time guaranteeing that distance students have access to the same print reference sources as on-campus students have. LIS instructors engaged in more online reference source instruction, and in some cases this was because of the limitations of what students had available to them and what instructors could do with a source via an online class. They also found wide variation in what, and how, LIS programs teach in their basic reference class.

Panelists at the Reference Renaissance conference in 2008 were charged to identify the "most critical skill in reference librarianship." The plenary panel was composed of two library educators and three library directors. Tellingly, the ability to find answers to factual questions in print sources was rarely mentioned as one of the most important skills. Instead, interpersonal and technological skills (which are more closely aligned than ever) are emphasized. LIS educator David Lankes said,

reference must shift to a co-learning environment. In this kind of class students and instructors learn together while working on real projects.... Reference librarians

... must build bridges to the communities they serve

... to be subversive change agents. ${ }^{8}$

LIS educator Marie Radford emphasized three areas of importance: communication, research and subject knowledge, and emotional intelligence and cognitive agility. ${ }^{9}$ Of these, only research and subject knowledge would seem to imply knowledge of reference sources. Library directors also emphasized the ability for new librarians to be experts at communication and collaboration, with one indicating that reference training could be done on the job. ${ }^{10}$

\section{METHOD}

Several methods were used to gather data for this project. A survey was distributed to students in two different ALAaccredited LIS programs asking about their experience in their reference classes. A second survey was distributed to 
librarians, asking what they felt was necessary for new hires to know and what their specific reference situation was. (Note: both surveys are available upon request from the primary author.) Finally, semistructured interviews were conducted with library practitioners, asking them about their reference experience. This allowed us to explore the problem from the points of view of LIS students and LIS practitioners.

\section{Reference Student Survey}

The first survey was directly distributed to students at two different ALA-accredited LIS programs. It was also distributed to faculty at four other LIS programs, with the request that they distribute it to their reference classes. The survey contained 26 questions, and the general purpose was to ask how they felt about their reference instruction and assignments. Questions included how often students went to the library for their reference assignments, how far they had to travel to get to an academic library, and whether visiting the library helped them understand sources and the nature of reference work.

\section{Surveying Reference Practitioners}

The second survey, which was directed at practitioners, aimed to provide a more critical view of LIS education, questioning how their employers and colleagues in libraries perceive the skills and abilities of students who had recently completed their schoolwork. Invitations to participate in the survey were distributed at two state library association conferences, which were attended by public, academic, and special librarians. To get results from a wider representation of reference librarians, the survey was distributed to two electronic mailing lists, PUBLIB (for public librarians) and LIBREF-L (for reference librarians). We received 285 total responses. We do not have number of reference librarians in the states where the survey was distributed, subscribers to PUBLIB, or subscribers to LIBREF-L. Because we do not know how what the population is, we cannot make any sampling determinations.

The practitioner survey had two foci: their own practice of librarianship, and what they seek from or how they regard new reference hires. Regarding their own practice, questions included:

- How is their reference model structured (i.e., tiered or traditional)?

- What reference sources were utilized most frequently?

- What types of questions are they most often asked (i.e., in-depth research, or factual)?

- Do they tend to use more print sources to answer questions, or more online sources? Of the online sources, do they use free or subscription sources more frequently?

Questions regarding new hires included:

- Are new hires regarded as bringing adequate skills and abilities to use electronic and print sources?
- Do they feel that new hires are adequately trained to use both print and electronic reference sources?

- What sources were critical for new hires to master; were there certain tools that new hires need to know about?

Many questions included a comment section so practitioner respondents were able to clarify or qualify their answers.

\section{Interviews}

After the surveys were analyzed for results, interviews with practitioners were performed to address some inconsistencies between practitioners' views. Participants were from two academic libraries and three public libraries in the state of Missouri. Interviews were semistructured, with three initial questions about reference practice. However, discussions ranged widely, to allow the participants to discuss the issues that were most important to them. Questions focused on what sources the librarians most often used, what reference students ought to be taught, whether students could find those sources in the practitioner's library, and whether it was important for students to learn about print resources.

\section{RESULTS}

\section{Student survey}

Most of the students who responded to the survey responded positively. They felt that they were learning a lot of new things and were pleased that they had been required to use both print and electronic reference sources. As shown in table 1, most felt that assignments involving print resources helped them understand the nature of reference work, understand reference sources, and how those sources are organized. Over half of all respondents were not working in libraries, and the assignments requiring the use of print sources gave them an opportunity to develop skills in the reference section of the library. Some students reported discussing the assignment with librarians, to find out how a professional might go about finding the answers. But because student respondents had not worked as reference librarians, their feelings of satisfaction or dissatisfaction with the curriculum were, in many ways, divorced from the context that reference work would otherwise provide.

The accessibility of print and online sources influenced students' use of these sources. Students reported that it was less time consuming to find information online. Some reported that they just couldn't spend many hours in the library to do an assignment, so they would make a quick tour of the reference section and get out of it what they could after finding the answers online. Another student reported that there just weren't many good print sources available at the library, which necessitated searching online. When given the choice, students were more likely to turn to online sources than print sources to complete assignments, even when they were required to use print resources (sometimes comparing 


\section{FEATURE}

Table 1. Reference Students' Opinions on Assignments and Library Visits

Survey Questions

\begin{tabular}{ccc} 
Yes & No & Total \\
\hline 93 & 7 & 100 \\
97 & 8 & 105 \\
\hline 94 & 11 & 105 \\
\hline 87 & 18 & 105 \\
\hline 86 & 19 & 105 \\
\hline 95 & 10 & 105 \\
\hline
\end{tabular}

Do you feel that visiting the library helped you understand reference sources?*

Do you think the source assignments helped you understand the nature of reference work?

Do you think the source assignments helped you understand the organization of reference sources?

During this class, did you become more comfortable using computers for research?

Based on your experiences, do you think that the use of print sources should be required for completion

of reference assignments?

Do you feel that the class provided you with adequate skills for an entry-level position in reference work?

*Some students did not visit the library, and therefore did not answer this question.

Table 2. First Source Type Consulted by Reference Students

\begin{tabular}{|lc}
\hline Source Type Consulted & No. \\
\hline Used print first & 39 \\
\hline Used online first & 63 \\
\hline Used only print & 1 \\
\hline Used only online & 2 \\
\hline
\end{tabular}

Table 3. Students' Prior Familiarity with Print Resources

\begin{tabular}{|lc|}
\hline Degree of Familiarity & No. \\
\hline Not at all & 1 \\
\hline Not really & 10 \\
\hline Yes, vaguely & 69 \\
\hline Yes, intimately & 25 \\
\hline
\end{tabular}

Table 4. Employment Situations for Reference Students

\begin{tabular}{lccc}
\hline Student Employment & Full Time & Part Time & $\begin{array}{c}\text { Volunteer/ Intern } \\
\text { Total }\end{array}$ \\
Total in nonlibrary employment & 51 & 20 & 0 \\
Total employed in libraries (includes volunteers and interns) & 31 & 18 & 6 \\
\hline
\end{tabular}

$\mathrm{N}=110$, totals are more than $100 \%$ because of students having multiple jobs

organization, etc., to their online sources). Most students began with online sources, though some began with print sources and two used only electronic sources, as shown in table 2 .

Students were asked whether they were familiar with print reference resources before taking the reference class. As shown by table 3, most students indicated that they were vaguely familiar with print resources. Table 2 notes that a majority of students said that print sources should be required for reference homework assignments, despite the difficulties of accessing these sources.

To gauge whether students' employment status affected their class engagement and ability to review print reference sources, we asked students if they worked and what their jobs were. Table 4 demonstrates the number of students employed in full-time and part-time jobs, including whether those were library-related jobs or outside jobs. Jobs for those who worked outside the library included full-time parent, auto mechanic, psychologist, writer, etc. Table 5 indicates the library departments that reference students worked in. Most of the students who worked in libraries were employed in Technical or Access Services.

Students employed full-time may have schedules that conflicted with library open hours. Students from rural areas have limited access to libraries with extensive print reference collections, and this is a particular concern when online programs are marketed as being available anywhere and at any time. Students were asked how far they had to travel to get to a library, and whether they felt they had to travel a long way (to ask them to provide both an objective and subjective measurement of distance). Table 6 shows the distances students had to travel. Further, it wasn't always the case that students who worked in libraries had easy access to reference sources. One respondent reported that she wasn't allowed to use the library for school while at work, which didn't leave her many hours there to do schoolwork.

\section{Practitioner Survey}

The majority of practitioner respondents, 71 percent, worked 
in public libraries. Only 27 percent worked in academic libraries, and four respondents worked in another library type. Patron interactions were usually in person or synchronous, as shown in table 7. Many said that most of their patron interactions are in person, and the second most often used method

Table 5. Library Departments Employing Reference Students

\begin{tabular}{lc}
\hline Department & No. \\
\hline Access Services (circulation, shelving, interlibrary loan) & 26 \\
\hline Reference/Public Services & 15 \\
\hline Other & 10 \\
\hline Technical Services (cataloging, acquisitions, etc.) & 46 \\
\hline Administration & 23 \\
\hline Maintenance & 1 \\
\hline Information Technology & 1 \\
\hline
\end{tabular}

Table 6. Reference Students' Travel Distance to Library

\begin{tabular}{lcc}
\hline Travel Distance & Any Library & Academic Library \\
\hline Less than $1 \mathrm{mi}$. & 38 & 20 \\
\hline 1-5 mi. & 49 & 25 \\
\hline -20 mi. & 16 & 39 \\
\hline More than $20 \mathrm{mi}$. & 3 & 22 \\
\hline Total respondents & 106 & 106 \\
\hline
\end{tabular}

of communication was telephone. Chat, video chat, and email reference made up a smaller percentage of total time. Public librarians reported mostly face-to-face and telephone interaction, while academic librarians reported face-to-face and chat/instant messaging. "Other" types of reference interactions reported were through the mail, through Facebook, and through personal interactions at instructional sessions. Table 7 also shows how practitioners devoted their reference time. While most of the librarians devoted less than 25 percent of their time to in-depth reference consultations, there were some respondents who spent most of their time doing so. Most practitioners still spent a good deal of time answering factual questions, while technology issues were perceived as consuming the most time. Public librarians reported a fair number of directional and technology questions; academic librarians were more likely to report in-depth research consultations.

When asked what source format librarians preferred to use with patrons, 55 percent (112 out of 205) of respondents preferred online subscription services. Twenty-four percent (49 out of 206) of the librarians chose free Internet sources, while 22 percent (44 out of 203) chose print sources. Both academic and public librarians preferred to use fee-based databases over print or web resources. The most important print resources were general dictionaries and medical resources, while sources of least importance were almanacs, reader advisory sources, and geographic sources. The relative importance of general sources like dictionaries and encyclopedias may stem from their generality: they are useful in many situations and with many audiences. By contrast, the diversity of scores on reader advisory sources suggests a difference between public libraries, where leisure reading is emphasized,

Table 7. Percentage of Time Spent on Question Type and Percentage of Questions Asked through Various Communication Modes

\begin{tabular}{|c|c|c|c|c|}
\hline $\begin{array}{l}\text { What Percentage of Questions is Asked Using the } \\
\text { Following Methods of Communication? }\end{array}$ & $0-25 \%$ & $25-50 \%$ & $50-75 \%$ & $75-100 \%$ \\
\hline Face-to-face & 8 & 39 & 108 & 49 \\
\hline Telephone & 98 & 86 & 18 & 3 \\
\hline Chat or IM & 172 & 17 & 2 & 1 \\
\hline Video chat & 165 & 0 & 0 & 1 \\
\hline E-mail & 164 & 28 & 5 & 1 \\
\hline Other & 102 & 4 & 0 & 1 \\
\hline $\begin{array}{l}\text { What Percentage of Time at Your Library is Spent } \\
\text { Answering the Following Types of Questions? }\end{array}$ & $0-25 \%$ & $25-50 \%$ & $50-75 \%$ & $75-100 \%$ \\
\hline Directional & 87 & 82 & 33 & 4 \\
\hline Factual & 63 & 114 & 24 & 3 \\
\hline Technology issues (printers, software programs, etc.) & 49 & 94 & 24 & 3 \\
\hline In-depth research consultation & 165 & 28 & 9 & 3 \\
\hline
\end{tabular}




\section{FEATURE}

Table 8. Practitioners' Views on Importance of Print Sources to Library

\begin{tabular}{|c|c|c|c|c|c|}
\hline Print Source & $\begin{array}{c}\text { Very } \\
\text { Important }\end{array}$ & $\begin{array}{l}\text { Somewhat } \\
\text { Important }\end{array}$ & $\begin{array}{c}\text { Not Very } \\
\text { Important }\end{array}$ & Unimportant & Ranking* \\
\hline Dictionaries (general) & 62 & 94 & 43 & 11 & 2.01 \\
\hline Dictionaries (subject-specific) & 27 & 87 & 77 & 11 & 2.36 \\
\hline Encyclopedias (general) & 56 & 91 & 49 & 12 & 2.08 \\
\hline Encyclopedias (subject-specific) & 51 & 94 & 54 & 6 & 2.07 \\
\hline Almanacs & 34 & 71 & 79 & 22 & 2.43 \\
\hline Geographic sources & 31 & 93 & 67 & 9 & 2.27 \\
\hline Readers' advisory sources & 48 & 63 & 54 & 43 & 2.44 \\
\hline Medical sources & 94 & 75 & 30 & 9 & 1.78 \\
\hline Legal sources & 76 & 79 & 44 & 11 & 1.95 \\
\hline
\end{tabular}

*Ranked from 1 to 4; smaller number = greater importance.

Table 9. Relative Importance to Practitioners of New Hire Skills

\begin{tabular}{|c|c|c|c|c|c|}
\hline New Hire Skills & $\begin{array}{c}\text { Very } \\
\text { Important }\end{array}$ & $\begin{array}{l}\text { Somewhat } \\
\text { Important }\end{array}$ & $\begin{array}{l}\text { Not Very } \\
\text { Important }\end{array}$ & Rank* & Total \\
\hline $\begin{array}{l}\text { Awareness and ability to use a } \\
\text { wide variety of print resources }\end{array}$ & 91 & 105 & 22 & 1.68 & 218 \\
\hline $\begin{array}{l}\text { Awareness and ability to use a } \\
\text { wide variety of fee-based data- } \\
\text { bases (e.g., EBSCOHost) }\end{array}$ & 140 & 59 & 17 & 1.45 & 216 \\
\hline $\begin{array}{l}\text { Awareness and ability to use a } \\
\text { wide variety of free-web Internet } \\
\text { resources }\end{array}$ & 151 & 66 & 1 & 1.31 & 218 \\
\hline $\begin{array}{l}\text { Ability to formulate effective } \\
\text { online searches }\end{array}$ & 191 & 25 & 1 & 1.12 & 217 \\
\hline $\begin{array}{l}\text { Interpersonal skills (with patrons } \\
\text { and colleagues) }\end{array}$ & 211 & 7 & 0 & 1.03 & 218 \\
\hline $\begin{array}{l}\text { Technological skills (other than } \\
\text { searching) }\end{array}$ & 113 & 102 & 1 & 1.49 & 216 \\
\hline Managerial experience & 11 & 90 & 107 & 2.53 & 208 \\
\hline
\end{tabular}

*Ranked from 1 to 3; smaller number = greater importance.

and academic libraries. Academic librarians viewed subjectspecific encyclopedias, subject-specific dictionaries, and medical sources as the most important print sources. Public librarians' preferred print sources were medical sources, legal sources, and general encyclopedias (see table 8).

When asked to rank traits and abilities they sought when hiring a new reference librarian, the most important quality was possessing excellent interpersonal skills, selected as "very important" by 97 percent of respondents. Ability to formulate effective online searches was the second-most important factor. In fact, academic librarians preferred the ability to formulate effective online searches slightly more than good interpersonal skills, while public librarians' top two preferences were interpersonal skills and effective online searching. The third-most important was awareness and ability to use free web resources. Awareness and ability to use fee-based databases was fourth-most important, and technological ability (other than searching) was fifth-most important. Only then does awareness and ability to use print resources make its appearance in the list, and only managerial experience ranked lower than ability to use print resources (see table 9).

A majority of practicing librarians believe that new hires 
Table 10. Practitioner Opinions of New Hires' Training and Skills

\begin{tabular}{lcc}
\hline $\begin{array}{l}\text { New Hires Have Adequate Training and } \\
\text { Skills to: }\end{array}$ & Yes & No \\
$\begin{array}{l}\text { Know the best sources to use to answer } \\
\text { reference questions. }\end{array}$ & 64 & 152 \\
\hline $\begin{array}{l}\text { Use print sources. } \\
\begin{array}{l}\text { Use online databases or electronic subscrip- } \\
\text { tion sources. }\end{array}\end{array}$ & 123 & 88 \\
\hline \begin{tabular}{l} 
Use free Internet sources for reference work. \\
\hline
\end{tabular} & 145 & 61 \\
\hline
\end{tabular}

are adequately trained in using print sources, and more believe they are adequately trained in electronic sources (see table 10). However, most practicing reference librarians felt that new hires did not know the best sources to answer reference questions. This was viewed as a skill that would come with additional on-the-job experience and familiarity with the library's unique collection. One comment, typical of almost forty others, was, "So much of what we do and how we answer questions has to do with what is unique to a particular collection and the patron or patron group being served. In the beginning sometimes these are not apparent because this is a learned skill set." Another respondent commented, "New hires know what their professors tell them, and this is often woefully out of date."

Some librarians who did not think that students are adequately trained thought that it was due to the online format of the class: "Many programs have become online only. It is very hard to teach these skills virtually and often I run into LIS students who are doing research to learn to use tools in my public library stacks. They are not always equipped well through that online experience." Some commenters noted that new hires were more comfortable with electronic sources than print. One recently employed librarian responded: "No attention was paid to print resources. And although they are not used as frequently as on-line databases, I would have liked to learn at least something about how to use them."

Although 58 percent of practicing librarians felt that new hires were adequately trained on print sources, there were still several comments that indicated perceptions of print as either a dying source or an ignored source. Comments from practicing librarians indicated that print sources were used less frequently in libraries, and that they appeared to be taught less frequently as well. When asked what print, fee-based database, and free web sources every new hire should know, we received literally dozens of unique answers, suggesting the regional nature of reference source suitability. Nonetheless, there was some consistency among answers. Table 11 shows the most-frequently provided answers. Multiple respondents noted that some sources are easier to use in print, and many lamented that the Statistical Abstract would not be released in a print edition in the future. However, several respondents noted that they were phasing out or sharply weeding their print reference collections, and that they did not often use their print collections. Some respondents said that print was not emphasized enough in LIS education, while one respondent noted that there is "too much focus on using print in library school." Regarding web sources, the most frequently recommended sources for new hires to learn were government web sources. Medical and legal sources took precedence here. Respondents who commented on fee-based databases emphasized that students should have experience searching the most popular database aggregators, while specific databases were less emphasized.

Practicing reference librarians had quite a bit more confidence in students' ability to use electronic resources, including databases and the free web. Even here, though, they acknowledged that using sources on the job was necessary to developing a fuller understanding.

Much of this experience comes from on the job training; database training can show specific search strategies but much is gained by actually searching for information for a customer or for a specific purpose. Artificial scenarios don't always replace the real reference interactions.

Students did feel that what they learned in class regarding databases was invaluable:

Even though I personally have no excuse for not knowing about the wealth of sources available in proprietary databases, there was a lot I was not familiar with. Being exposed to many of those that I was not using before has really changed my approach to research.

Google received positive and negative reviews among the practicing librarians. While one commenter suggested that "the world is attached to Google," another said that it was the first "source," in quotation marks, that new hires always turn to.

\section{Interviews}

Interviews were conducted to explain some of the inconsistencies that were in the survey data, especially as it compared to the literature regarding reference. The first interview was with two academic librarians who work in primarily commuter college campuses. They both use online resources much more frequently than print, and reported that much of their reference work does take place online. They use a variety of tools (especially Meebo) to instant-message with their patrons, even those who are in the library (one said that the students don't want to lose their place and lug all of their books to the desk to ask a question). Their online patrons want answers quickly, and they want online sources. Their in-person reference model also has evolved-they both use a consultation model for in-depth research, which they say is actually more important now than the limited interactions involved in answering questions on the reference desk. One 


\section{FEATURE}

Table 11. Answers to Sources New Hires Should Know That Received Two or More Recommendations, Listed from Most-Often to Least-Often Mentioned

\begin{tabular}{|c|c|c|}
\hline Print & Fee-Based Electronic & Free Web \\
\hline Statistical Abstract of the United States* & EBSCO & Census Bureau \& American FactFinder \\
\hline State Statutes & Gale & Google Scholar \\
\hline Value Line, MorningStar & ProQuest & Google \\
\hline Auto repair manuals (Chilton's, Haynes) & Lexis-Nexis & Google Books \\
\hline Local government administrative codes & ReferenceUSA & Wikipedia \\
\hline $\begin{array}{l}\text { Literary criticisms (e.g., Contemporary } \\
\text { Literary Criticism) }\end{array}$ & NoveList & $\begin{array}{l}\text { Government Health Sites: MedlinePlus, } \\
\text { PubMed }\end{array}$ \\
\hline Style guides (APA, Chicago, MLA) & AllData Auto Repair Database & Internet Movie Database (IMDB.com) \\
\hline Reader's Guide & Literature Resource Center & Internet Public Library \\
\hline World Book Encyclopedia & PsycINFO & WorldCat \\
\hline World Almanac & MedLine & Internal Revenue Service (irs.gov) \\
\hline Price guides (for cars, stamps, coins, etc.) & DIALOG & Library of Congress (loc.gov) \\
\hline Consumer Reports & NewsBank & CIA World Factbook \\
\hline City directories \& telephone books & & State Department \\
\hline US Code of Federal Regulations & & Amazon.com \\
\hline Oxford English Dictionary & & USA.gov \\
\hline Occupational Outlook Handbooks & & National Center for Educational Statistics \\
\hline
\end{tabular}

*Commenters mentioned that even though it is going out of print, the print version is far easier to use than the electronic version.

of the academic librarians reported that they have reduced the size of their reference collection by approximately 90 percent, replacing it with couches and group study spaces. Volumes in the reference collection that were not out of date now circulate. The other librarian said that her library had not done this, but she hoped they would.

Three public librarians were interviewed, a business librarian from a large metropolitan library, the head of reference from an urban library, and the head of reference from a mediumsized public library. Public librarians agreed that new hires should be well-versed in print reference sources-especially those with enduring value. Their reported use of space was quite different: they had not significantly reduced the size of their reference collection, and they did not have plans to do so. Most of their reference work took place in person. While they reported that they often consulted online sources (especially databases) for reference questions, they also said that print resources were important. Getting rid of print resources was viewed as fiscally irresponsible because during times of financial crisis (if, for instance, they had to slash their budget allocation for databases), they could still function if their reference section was intact. One librarian did say that the library circulates more single-volume reference works (such as subject encyclopedias) than they did in the past. This allowed them to bring out volumes that had previously been in closed stacks, so their total reference space allocation was unchanged. There was not much consensus between academic and public librarians about sources or space allocation.

Both academic and public librarians agreed that there are some sources that are no longer needed in print, such as directories. A few exceptions were noted, such as print directories that provide added value, or directories with historical value (such as historic city directories). Both groups cited the invisibility of online reference sources. While the online sources offer advantages of access and ease of use over print resources, they are not used much, justifying their continued expense. When they were asked about the most important resources for new librarians to know, academic and public librarians agreed: law and business sources were both often in demand and difficult to learn. Students need to be able to use them.

\section{CONCLUSION}

This research project showed contradictions in the field, demonstrating that there is no easy answer to the problem of 
"what to teach." Academic and public librarians, our two largest groups of respondents, had slightly different priorities in terms of sources necessary for new hires to know. It has been suggested that reference sources might be better learned on the job than in the LIS curriculum. At the Reference Renaissance conference, one practitioner suggested reference sources could be removed from the reference curriculum and taught on the job. Similarly, the practitioners surveyed suggested that some sources were specific to individual libraries. Students valued print sources and learned from them, but many were at least familiar with them before their reference courses. Academic and public libraries appear to be diverging somewhat in their reference offerings, with public libraries serving more face-toface clientele than academic librarians do.

Interviews in this study found that librarians who work on a commuter campus made frequent use of online sources. However, the survey found that the majority of the survey respondents' reference work is still done in a traditional manner with live people. Perhaps this is because most survey respondents worked in public libraries. It also found that librarians regard print resources highly (citing issues such as authority and ease of use), but even those who regard print highly most often rely on subscription sources for their work. Additionally, data from the surveys didn't reflect trends in the literature. Generally, the literature says that reference work (including the reference interview) is increasingly being conducted online, even as door counts are up. The surveys that the practitioners completed indicated that much more reference work is conducted in person, and only rarely, if ever, online. Perhaps as our patrons turn increasingly to online sources, they need human contact and guidance, and will take advantage of that where they can find it. Evidence suggests that even as the death of the reference desk is predicted, the reference librarian is still necessary, as an information guide or mentor if not as an information demigod.

The students recognized the value in using print resources as a means for understanding the organization of information and librarianship, an idea that was repeated by librarians in interviews. In other words, while most answers to factual questions are found in online resources (as reported in both surveys and interviews), there is an enduring value in having students use print resources, which goes beyond the ability to answer simple factual questions. The student survey indicated that students seemed to feel that they benefited from using print resources, as well as from perusing the physical reference collection. For example, one student said "the catalog search for an appropriate reference coupled with the actual exploration of the source for an answer was vital. I also learned a lot from asking questions at the reference desk and seeing how professionals tackled the questions." Many students enjoyed seeing how reference professionals worked in situ, and the interaction between the students and the professionals was fruitful for the students' professional development.

Our findings and observations point to reference instruction and reference services and sources going online. Still, many review articles (in RUSQ, for instance) are reviewing reference books. There is a love of books, and they are still being published, but librarians do seem to use more online reference sources than print sources. Despite the incongruities, there were some helpful pieces of advice offered, and some trends that emerged from the data, regarding teaching the reference curriculum in this time of upheaval. Some of these findings fit naturally with online education. Others are not easy, but not impossible.

1. Print reference sources provide students with a conceptual model of organization of information. While they might not be the most used sources on the job, comparing print with online sources will aid their understanding.

2. Students need more experience with specialized reference works and databases, such as business and legal sources. These are important in both academic and public settings, and are often relegated to a specialized (elective) reference course.

3. One reality of the reference desk is that librarians need to be adept at using (and explaining) technology. They should be able to use a variety of different word processing programs, to troubleshoot hardware and software, and generally be creative problem solvers of technological issues. Professors should try to integrate assignments into their courses that require the students to develop these skills throughout the curriculum. Many of the respondents said that they spend much of their time helping patrons use programs and troubleshooting technology. While this is not technically a part of reference work, the reality is that it is a major component of the job. Skilled and technologically agile librarians will become valuable contributors to their organization.

4. Since practitioners must be able to communicate well with people — both online and in person-students also need to be taught these skills. As several of the practitioner respondents noted, online education is not giving the students experience with the most important skill: communication. LIS educators need to use tools and develop assignments that enable the students to develop their inperson and online communication skills. Reference class should cover communication, allowing students to identify problems and propose solutions to communication barriers. This is more difficult in the online environment, but it is certainly not impossible.

What lessons should LIS educators take from these results? First, that reference services, like other critical services offered by libraries, varies between library types and that this variation means that a one-size-fits-all course may be inappropriate. Reference courses oriented toward sources probably need to teach 'how to search' and cross-source skills rather than 'what to search' and specific sources. Even so, they can use the list of commonly recommended sources in our findings to cover some major sources. Our findings also suggest that students who have ambitions of going into reference services will need a practical supplement to their 


\section{FEATURE}

academic experience. Subject-specific reference classes might need to discuss the information needs of people who might use those sources, and how those differ by environment. A doctor seeking health information in a health sciences library has significantly different needs from a teenage mother seeking health information from her public library. Since LIS programs cannot limit themselves to admitting only those students who have worked in libraries, experience of this sort should be achieved through practicum or assistantship experiences.

What lessons should librarians take from these results? Many practitioners clearly already knew that new hires need some on-the-job training to become oriented to a particular community and the sources that serve its needs. Reference librarians should also keep in mind that reference courses have multiple populations to serve and topics to impart. Information about communities specific to a particular library may be best imparted to new hires on site, by the librarians who serve that community and know it best. One survey respondent said she considered training on local sources to be the job of the employing library, rather than the LIS program. Even so, librarians should also feel free to communicate with LIS programs, either through organizations like the Reference and User Services Association or individually, by visiting or setting appointments with faculty.

This study provided a bit of clarity to the question, "What sources should be taught in library school?" While some sources have overarching reach, others are community-specific and best taught on the job. However, this study suggests some new lines of research to better clarify libraries' reference situations. Evidence suggests that academic and public libraries have different needs from their reference personnel. This naturally has implications for the future of the reference curriculum. Evidence also suggests that the reference sources used and preferred are online fee-based sources, while the reference sources typically reviewed in journals are print-based. This may speak to a difference in priorities between publishers and reference librarians. Finally, with the proliferation of online sources and the disappearance of some print reference collections, more attention will have to be paid to new ways of learning those sources. While our student respondents noted that print sources helped them understand the arrangement of online sources, we may be inadvertently eliminating what online sources can help students learn about the arrangement of information within a source. These questions, provoked by this study, remain unanswered.

\section{References}

1. Margaret Landesman, "Getting It Right-The Evolution of Reference Collections," Reference Librarian no. 91/92 (2005): 5-22.

2. Biggs and Biggs, 1985, as quoted in Landesman, "Getting It Right," 10.

3. Eleanor Mitchell and Sarah Barbara Watstein, "Further Thoughts about Putting the User at the Center," Reference Services Review 35 , no. 1 (2007): 5-7.

4. Samuel Rothstein, "The Making of a Reference Librarian," Reference Librarian no. 25/26 (1989): 321-50.

5. John V. Richardson, "Learning Reference Work," in KnowledgeBased Systems for General Reference Work: Applications, Problems, and Progress (San Diego, Calif.: Academic Pr. 1995): 3-34.

6. Denice Adkins and Sanda Erdelez, "An Exploratory Survey of Reference Source Instruction in LIS Courses," Reference \& User Services Quarterly 46, no. 2 (Winter 2006): 50-60.

7. Marie L. Radford and R. David Lankes, eds., Reference Renaissance: Current and Future Trends (New York: Neal-Shuman, 2010): 17

8. Ibid., 20

9. Ibid., 35 .

10. Ibid., 30 